Mr Slobodan Simić, kapetan, dipl. inž.

Vojna akademija, Beograd

\section{ANALIZA KONTINUALNIH FREKVENCIJSKI MODULISANIH RADARSKIH SIGNALA PRIMENOM VREMENSKO-FREKVENCIJSKIH TRANSFORMACIJA I KORELACIONIH TEHNIKA}

UDC: 621.396 .962 .2

Rezime:

U radu su analizirana dva metoda za detekciju i procenu parametara radarskih signala s malom verovatnoćom presretanja, pri čemu ne postoji saradnja između prijemnika i predajnika. Prvi algoritam čini analiza signala pomoću vremensko-frekvencijskih transformacija zajedno sa tehnikama za prepoznavanje oblika. U osnovi drugog algoritma detekcije je procena periodične autokorelacione funkcije. Analizirani su kontinualni frekvencijski modulisani radarski signali (FMCW), često primenjivani u radarima s malom verovatnoćom presretanja. Korišćeni su test-signali, dobijeni eksperimentalnim putem. Realizovan je eksperiment $s$ realnim predajnikom i prijemnikom FMCW signala, a rezultati obrade primljenih signala prikazani su u radu.

Ključne reči: FMCW signal, vremensko-frekvencijske transformacije, periodična autokorelaciona funkcija.

\title{
FMCW RADAR SIGNAL ANALYSIS BY TIME-FREQUENCY REPRESENTATIONS AND CORRELATION TECHNIQUES
}

Summary:

Two LPI signal detection and parameter estimation methods are analyzed in a non-cooperative context. The first method is based on the time-frequency signal analysis along with pattern recognition techniques. The second one is based on the estimation of a periodic autocorrelation function. Frequency modulation continuous wave (FMCW) signals are analyzed as a class of waveforms often used in LPI radars. Experimentally obtained signals are used in tests. An experiment with a real FMCW signal transceiver and a receiver is carried out and the obtained signal analysis results are presented.

Key words: FMCW signal, time-frequency representations, periodically autocorrelation function.

\section{Uvod}

Velika vrednost proizvoda trajanja impulsa i širine zauzetog frekvencijskog opsega (TB, Time-Bandwidth product) upotrebljenog talasnog oblika (10000100000 ), pruža mogućnost LPI radaru da emituje signal sa niskim nivoom srednje snage $(<10 \mathrm{~W}$ za domete do $15 \mathrm{~km}[1])$, jer radarski prijemnik ostvaruje procesno pojačanje reda $40-50 \mathrm{~dB}$. To znači da je signal moguće registrovati sa zadovoljavajućom verovatnoćom detekcije, iako je odnos signal/šum na ulazu u radarski prijemnik vrlo mali $(<-40 \mathrm{~dB})$.

Dalje, LPI radari koriste antene sa vrlo niskim nivoom bočnih lobova $(<-40$ $\mathrm{dB}$ ), pa je presretanje po bočnim snopovima sa velikih rastojanja (nekoliko puta većih od dometa radara) otežano. Vrednost odnosa signal/šum na ulazu u presretački prijemnik u ovom slučaju je reda 
$-10 \mathrm{~dB}$, pa konvencionalni energetski detektori ne mogu da registruju ovakav radar ni sa mnogo kraćih rastojanja, reda dometa radara $[1,2]$.

U ovom radu prikazani su rezultati primene dva metoda za detekciju i procenu parametara na nepoznate LPI radarske signale. U osnovi prvog metoda je procena periodične autokorelacione funkcije (PACF) [2, $3,4]$, a u drugom se koriste vremensko-frekvencijske transformacije, TFR (Time Frequency Representation) [1, 2]. Ovi algoritmi sastavni su deo softvera koji savremenim presretačkim prijemnicima obezbeđuje: veće procesno pojačanje pri detekciji LPI radarskih signala; procenu širokog skupa parametara, dovoljnog za kvalitetnu klasifikaciju, kao i sintezu efikasnog ometačkog signala. $\mathrm{S}$ obzirom na to da se akvizicija $\mathrm{i}$ obrada signala vrši pre detektora ovojnice, ovakvi načini obrade spadaju u grupu koherentnih metoda. Prvi metod može se razvrstati i u kroskorelacione metode, s tim što se ne zahtevaju dva kanala [2].

\section{Model FMCW signala}

Za LPI radare, kao i za konvencionalne radare, vrlo je važno da autokorelaciona funkcija (ACF) primenjenog talasnog oblika ima niske nivoe bočnih lobova. Na taj način izbegava se maskiranje glavnih pikova slabijih ciljeva bočnim lobovima izraženih ciljeva. Širina spektra, obrnuto srazmerna trajanju podimpulsa, određuje rezoluciju po daljini. Kontinualni signal sa linearnom frekvencijskom modulacijom (LFM-CW), koji zadovoljava navedeni uslov, ustalio se kao jedan od najpopularnijih LPI talasnih oblika zbog relativno jednostavne reali- zacije predajnika i prijemnika. Sa razvojem platformi za digitalnu obradu signala, i ostali FMCW i PSK talasni oblici postali su atraktivni za projektante radara. Ova raznolikost mogućih radarskih signala usložila je projektovanje sistema za elektronsko ratovanje. Sofisticirani digitalni prijemnici koriste brojne algoritme, pri čemu svaki od njih, uglavnom, pokriva samo određeni skup mogućih tipova radarskih signala na ulazu u prijemnik. U radu su analizirani neki periodični FMCW signali.

Linearni FMCW signal prikazan je sledećom relacijom:

$$
\begin{aligned}
& s(t)=A e^{j\left(2 \pi f_{0} t+\pi k t^{2}\right)}, \\
& t \in[(2 n-1) T / 2,(2 n+1) T / 2], \\
& n \in Z, k=\frac{B}{T}
\end{aligned}
$$

gde je:

A - amplituda,

$\mathrm{f}_{0}$ - frekvencija signala nosioca,

B - širina zauzetog frekvencijskog opsega, $\mathrm{T}$ - modulacioni period.

Sinusni FMCW signal modeluje se na sledeći način:

$$
\begin{aligned}
& s(t)=A e^{j\left(2 \pi f_{0} t+b \sin \left(\frac{2 \pi t}{T}\right)\right)}, \\
& t \in[(2 n-1) T / 2,(2 n+1) T / 2], \\
& n \in Z, b=\frac{T B}{2}
\end{aligned}
$$

Signal primljen presretačkim prijemnikom predstavlja smešu korisnog signala $s(t)$ i šuma $n(t)$ :

$r(t)=s(t)+n(t)$ 
Odnos signal/šum definiše se kao:

$\rho=\frac{\bar{s}}{N}=\frac{A^{2}}{\sigma^{2}}$

gde je:

$\sigma^{2}$ - varijansa kompleksnog šuma, a

$\overline{\mathrm{s}}$ - srednja snaga signala.

\section{Eksperimentalni model scenarija sukoba LPI radar - presretač}

Radi dobijanja test-signala, istovetnih sa realnim LPI radarskim signalima, realizovani su funkcionalni modeli predajnika FMCW signala i softverskog prijemnika LPI signala. Postavka omogućuje prijem kontinualnog, frekvencijski modulisanog signala koji se prostire kroz slobodni prostor. Blok-šeme predajnika i prijemnika prikazane su redom na slikama 1 i 2 .

Za generisanje FMCW signala upotrebljen je HP 8620 Sweep Oscilator. Frekvencija osnovnog oscilatora ovog uređaja podešena je na $2,19 \mathrm{GHz}$, što nije tipič- no za LPI radare. Oni, uglavnom, rade $\mathrm{u}$ višim frekvencijskim opsezima [1]. Međutim, to nema uticaja na verifikaciju predloženog algoritma, jer se akvizicija i obrada podataka obavlja u osnovnom opsegu. Predajnik sadrži naponski kontrolisani oscilator HP 86222B (VCO - Voltage Controlled Oscillator), kojim se upravlja pomoću generatora talasnih oblika tipa MA 3733. Frekvencija signala na izlazu iz ovog generatora podešena je na 2 $\mathrm{kHz}$, tako da period FMCW signala iznosi $0,5 \mathrm{~ms}(\mathrm{PRI}=0,5 \mathrm{~ms}$, što je reda veličine PRI kod LPI radara). Amplituda signala na izlazu iz generatora MA 3733 podešena je tako da FMCW signal zauzima frekvencijski opseg širine $17 \mathrm{MHz}$, što rezultira TB proizvodom u iznosu od 8500 (TB $=0,5 \cdot 10^{-3} \cdot 17 \cdot 10^{6}=8500$, što je reda veličine TB proizvoda kod LPI radara). Prijemnik je podešen tako da je centralna frekvencija propusnog opsega $2,18 \mathrm{GHz}$, a njegova širina $26,1 \mathrm{MHz}$, što odgovara jednom kanalu hipotetičkog kanalskog prijemnika (channelized receiver; na primer, opseg od $16 \mathrm{GHz}$ pokriven je sa $8 \times$ $10 \times 8=640$ kanala po $25 \mathrm{MHz}$ ).

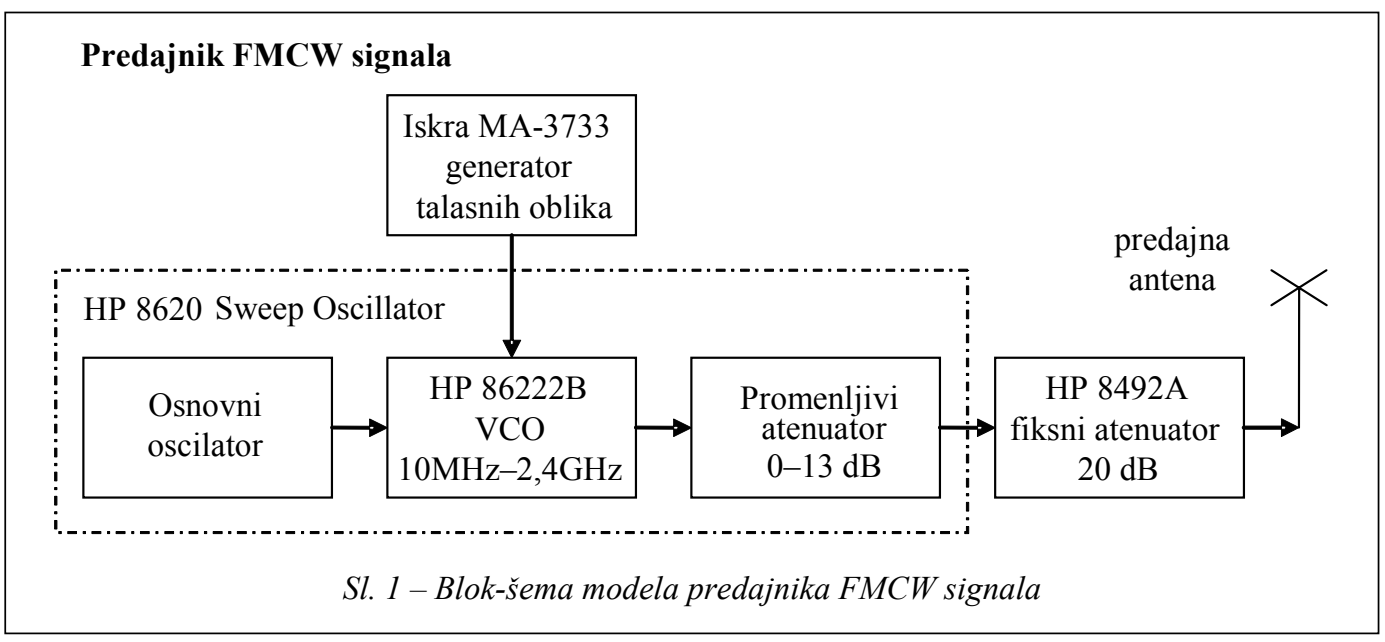




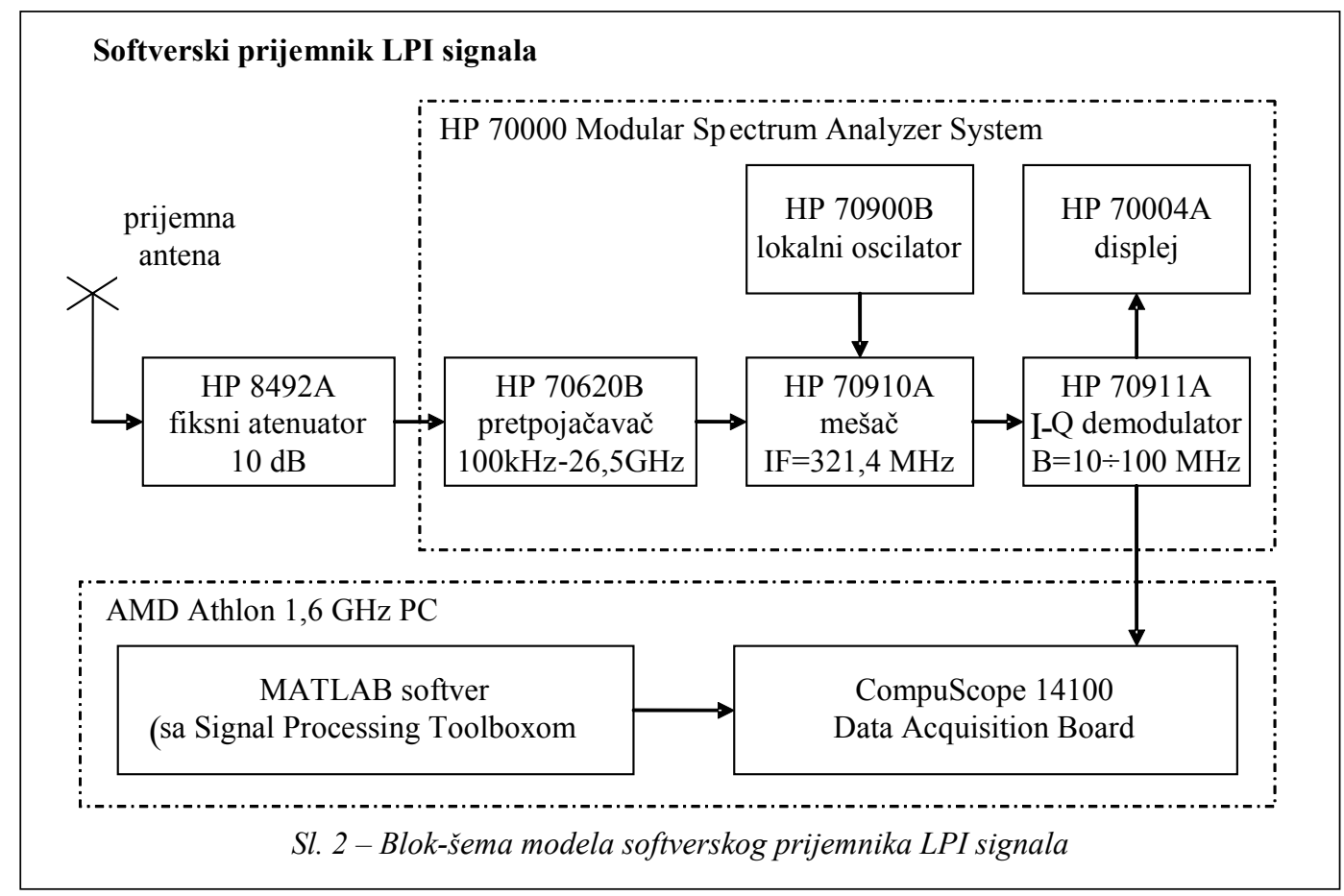

Fiksno slabljenje, koje je posledica propagacije u slobodnom prostoru, ostvareno je odgovarajućim položajem antena, uz dva fiksna atenuatora ( $20 \mathrm{~dB}$ na strani predajnika i $10 \mathrm{~dB}$ na strani prijemnika). Predajna snaga menjana je pomoću atenuatora ugrađenog u predajnik, kako bi se postigli različiti nivoi snage signala na ulazu u prijemnik, koji odgovaraju različitim daljinama detekcije. Na taj način ostvarene su različite vrednosti odnosa signal/šum na ulazu u prijemnik, pri nepromenjenim ostalim parametrima. Tako su modelovane različite udaljenosti radar-presretač. Postojeći promenljivi atenuator u sklopu predajnika HP $8620 \mathrm{C}$ može kontinualno da uzima vrednost iz opsega $[0,13] \mathrm{dB}$. To znači da se nivo predajne snage, a time $\mathrm{i}$ vrednost odnosa signal/šum na ulazu u prijemnik, može menjati u opsegu širine $13 \mathrm{~dB}$. Antene su postavljene tako da, pri izabranim vrednostima fiksnih atenuatora, opseg u kome se menja ovaj odnos iznosi $[-13,0]$ $\mathrm{dB}$. Iz tabele 2 [2] vidi se da ove vrednosti odnosa signal/šum nastaju na daljinama radar-presretač od $100 \mathrm{~km}(-13 \mathrm{~dB}) \mathrm{i}$ $25 \mathrm{~km}(-1 \mathrm{~dB})$, ako radar emituje signal snage $1 \mathrm{~W}$, sa odgovarajućim parametrima prijemnika kao u primeru iz [2].

$\mathrm{Na}$ slici 3 prikazan je predajnik FMCW, a na slici 4 analogni deo prijemnika, HP 70000 Modular Spectrum Analyzer System s fiksnim atenuatorom i antenom. Digitalni deo prijemnika čini PC računar (slike 5 i 6) sa PCI akvizicijskom karticom CompuScope 14100.

Korišćene su tri vrste talasnih oblika na izlazu iz generatora MA 3733, pa su dobijene tri vrste FMCW signala. Kada je primenjen testerasti talasni oblik, na izlazu iz predajnika dobijen je linearni 


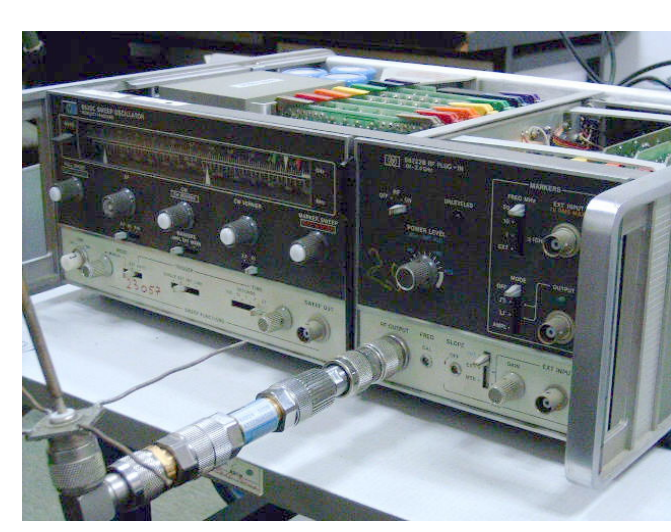

Sl. 3 - Predajnik linearnog FMCW signala

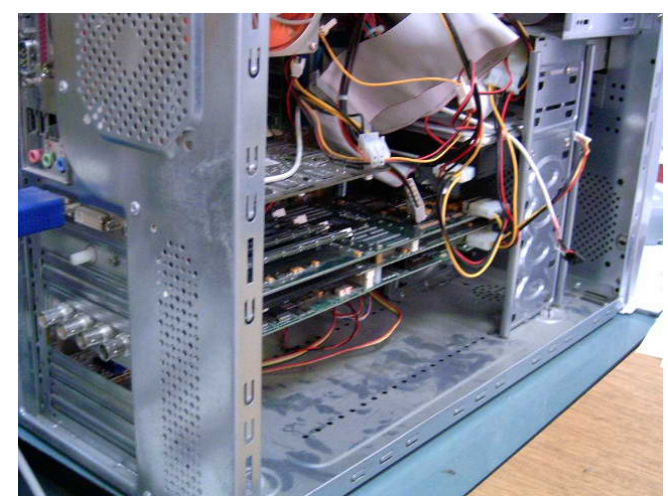

Sl. 5 - Digitalni deo prijemnika LPI signala

FMCW signal (LFM), dok je posle primene sinusnog talasnog oblika dobijen sinusni FMCW na izlazu iz predajnika (SinFM). Treći upotrebljeni talasni oblik je pravougaoni. Teorijski, primenom ovakvog talasnog oblika dobija se FMCW signal koncentrisan naizmenično oko dve frekvencije. Pošto upotrebljeni VCO HP 86222B ne može da isprati ovako brzu diskontinualnu promenu frekvencije, to je rezultujući FMCW signal nepravilan (polinomijalnog tipa - PolyFM) i zauzima frekvencijski opseg uži od $17 \mathrm{MHz}$.

Promenljivi atenuator u sklopu predajnika HP 8620C postavljan je na dve

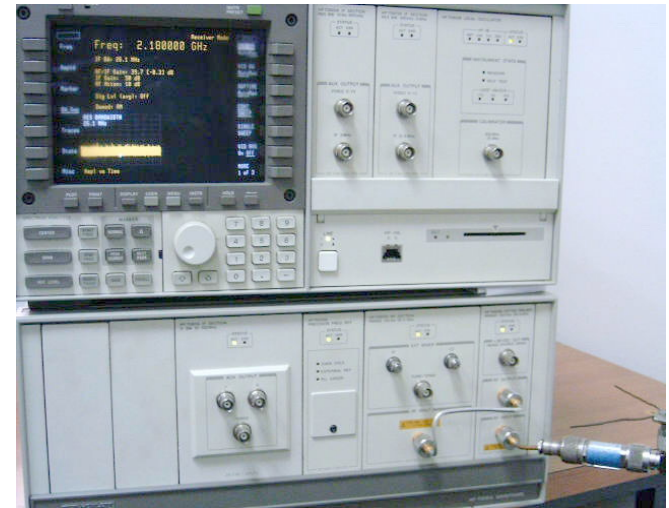

Sl. 4 - HP 70000 Modular Spectrum Analyzer

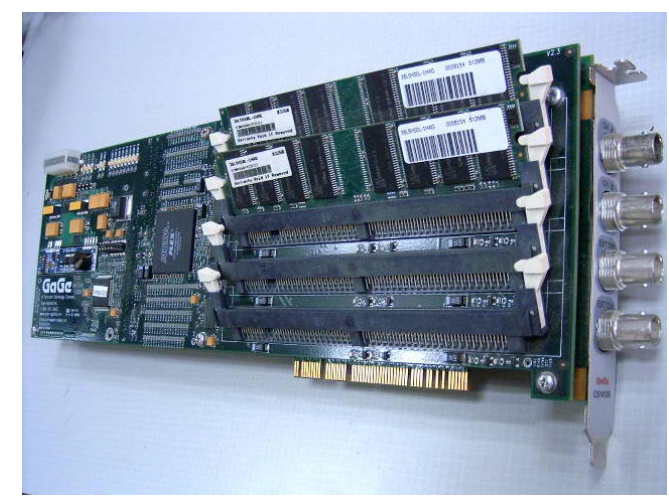

Sl. 6 - Gage kartica, CompuScope 14100

vrednosti, $0 \mathrm{~dB}$ i $-13 \mathrm{~dB}$, tako da je relativni nivo predajnog signala (snaga predajnog signala $-\mathrm{P}_{\mathrm{t}} \mathrm{u}$ odnosu na interni referentni nivo snage predajnika $-\mathrm{P}_{\mathrm{i}}$ ) iznosio $0 \mathrm{~dB} \mathrm{i}-13 \mathrm{~dB}$.

Dobijeni signali na izlazu iz I-Q demodulatora digitalizovani su pomoću PC računara sa PCI akvizicijskom karticom CompuScope 14100, sa frekvencijom odabiranja $50 \mathrm{MHz}$, odnosno periodom odabiranja $20 \mathrm{~ns}$. Na slici 7 prikazane su spektralne gustine srednjih snaga (SGSS) slučajnih procesa na ulazu u digitalni deo prijemnika. One su procenjene Welchovim postupkom na 


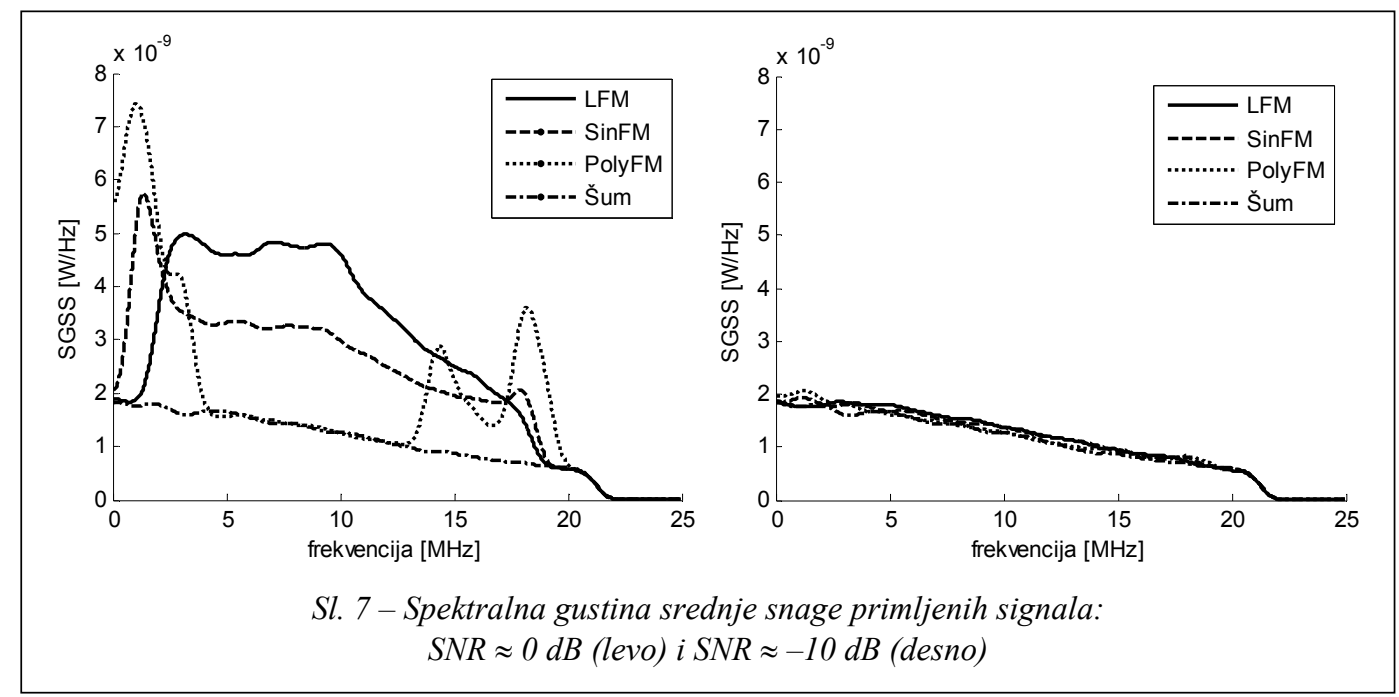

osnovu $2^{16}$ odbiraka, odnosno na intervalu $1,3 \mathrm{~ms}$. U levom delu slike 7 prikazane su SGSS za relativni nivo predajnog signala $0 \mathrm{~dB}$. Vidi se da su SGSS procesa, koji predstavljaju smeše signala i šuma iznad SGSS šuma, pa je moguće detektovanje ovakvih signala na bazi procene SGSS. Međutim, ukoliko se nivo snage predajnog signala smanji za $13 \mathrm{~dB}$, za isti iznos smanji se i nivo snage signala na ulazu u digitalni deo prijemnika. Tada se SGSS procesa koji predstavljaju smeše signala i šuma spuštaju do SGSS šuma i nemoguće ih je razlikovati. Grafici ovih SGSS prikazani su u desnom delu slike 7 .

U tabeli su prikazane srednjekvadratne vrednosti (snage) slučajnih procesa na ulazu u digitalni deo prijemnika i odgovarajući odnosi signal/šum. Snage slučajnih procesa dobijene su usrednjavanjem trenutne snage (po vremenu) i usrednjavanjem spektralnih gustina srednje snage (po frekvenciji). Usrednjavanje po vremenu izvršeno je na osnovu $2^{21}$ odbiraka, odnosno na intervalu od $42 \mathrm{~ms}$. Iz tabele se vidi da oba načina procene snage ovih procesa daju približne rezultate.

Srednjekvadratne vrednosti slučajnih procesa na ulazu u digitalni deo prijemnika i odgovarajući odnosi signal/šum

\begin{tabular}{|c|c|c|c|c|c|c|c|}
\hline Tip signala & \multicolumn{2}{|c|}{ Tip I (LFM) } & \multicolumn{2}{|c|}{ Tip II (SinFM) } & \multicolumn{2}{|c|}{ Tip III (PolyFM) } & \multirow{2}{*}{ Šum } \\
\hline $\mathrm{P}_{\mathrm{t}} / \mathrm{P}_{\mathrm{i}}[\mathrm{dB}]$ & 0 & -13 & 0 & -13 & 0 & -13 & \\
\hline $\begin{array}{c}\sigma^{2}[\mathrm{~mW}], \\
\text { po vremenu }\end{array}$ & 66,52 & 27,48 & 55,8 & 27,15 & 48,5 & 26,5 & 25,3 \\
\hline $\begin{array}{c}\sigma^{2}[\mathrm{~mW}] \\
\text { po frekvenciji }\end{array}$ & 67,6 & 27,32 & 56,0 & 27,2 & 48,14 & 26,6 & 25,37 \\
\hline $\begin{array}{c}\text { SNR [dB], } \\
\sigma^{2} \text { po vremenu }\end{array}$ & 2,1 & $-10,6$ & 0,8 & $-11,4$ & $-0,4$ & $-13,2$ & \\
\hline $\begin{array}{c}\text { SNR }[\mathrm{dB}], \\
\sigma^{2} \text { po frekvenciji }\end{array}$ & 2,2 & $-11,1$ & 0,8 & $-11,4$ & $-0,5$ & $-13,1$ & \\
\hline
\end{tabular}


Uz pretpostavku da su signali nekorelisani sa šumom, odnos signal/šum računat je kao:

$$
S N R=10 \cdot \log \left(\frac{\sigma_{s n}^{2}}{\sigma_{n}^{2}}-1\right)
$$

gde $\sigma_{\mathrm{sn}}^{2}$ označava snagu slučajnog procesa koji je smeša signala i šuma, a $\sigma_{\mathrm{s}}^{2}$ je snaga šuma. Iz tabele se vidi da su nivoi signala $\mathrm{i}$ šuma istog reda veličine (SNR je od $-0,5$ do 2,2 dB) kada je relativni nivo predajne snage $0 \mathrm{~dB}$. Kada se ovaj nivo smanji za $13 \mathrm{~dB}$, nivo signala spušta se znatno ispod nivoa šuma. Odnos signal/šum smanjuje se za $13 \mathrm{~dB}$, što je približno dobijeno i primenom (5), a rezultati su prikazani u tabeli.

Spektrogrami sva tri tipa signala za odnose signal/šum iz tabele prikazani su na slikama 8-10. Posmatrani su test-signali trajanja $1,3 \mathrm{~ms}\left(2^{16}\right.$ odbiraka). Primenjena je Haningova prozorska funkcija dužine 512 , uz preklapanje između prozora od $25 \%$, tako da su ovi spektrogrami, u stvari, digi- talne slike dimenzija $174 \times 512 . \mathrm{Sa}$ ovih slika uočavamo da se u vremensko-frekvencijskim transformacijama (u ovom slučaju to su spektrogrami) signal koncentriše oko tačaka grupisanih u linije koje predstavljaju promenu trenutne frekvencije tokom vremena. Ove linije moguće je vizuelno prepoznati i pri vrlo niskim odnosima signal/šum reda $-12 \mathrm{~dB}$, mada ne tako jasno kao pri višim SNR reda $0 \mathrm{~dB}$.

\section{Procena periodične autokorelacione funkcije}

U ovom odeljku izložen je algoritam predložen u radovima $[3,4]$, a predmet analize je periodični (s periodom jednakim bitskom intervalu) komunikacioni signal s proširenim spektrom, metodom direktne sekvence (SS DS). Ovde je pokazano da se isti algoritam može primeniti i na određenu klasu radarskih signala, a to su periodični signali s proširenim spektrom i visokim faktorom popune. U osnovi ovog algoritma jeste procena PACF-a.
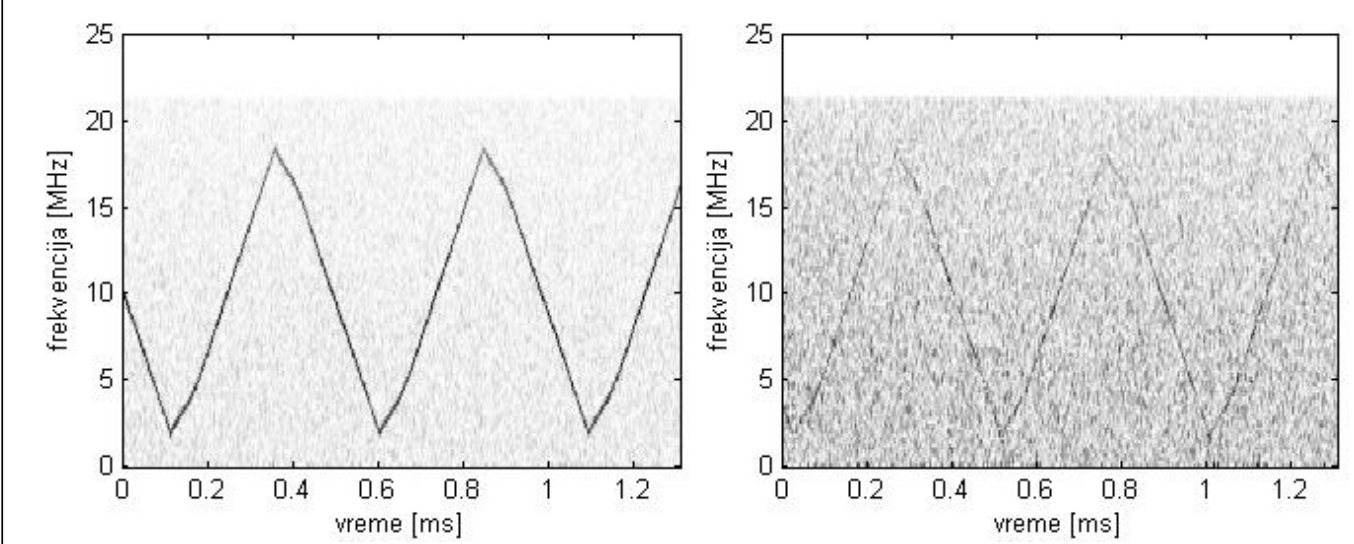

Sl. 8 - Spektrogram linearnog FMCW signala: $S N R=2,1 \mathrm{~dB}$ (levo) i $S N R=-10,6 \mathrm{~dB}$ (desno) 

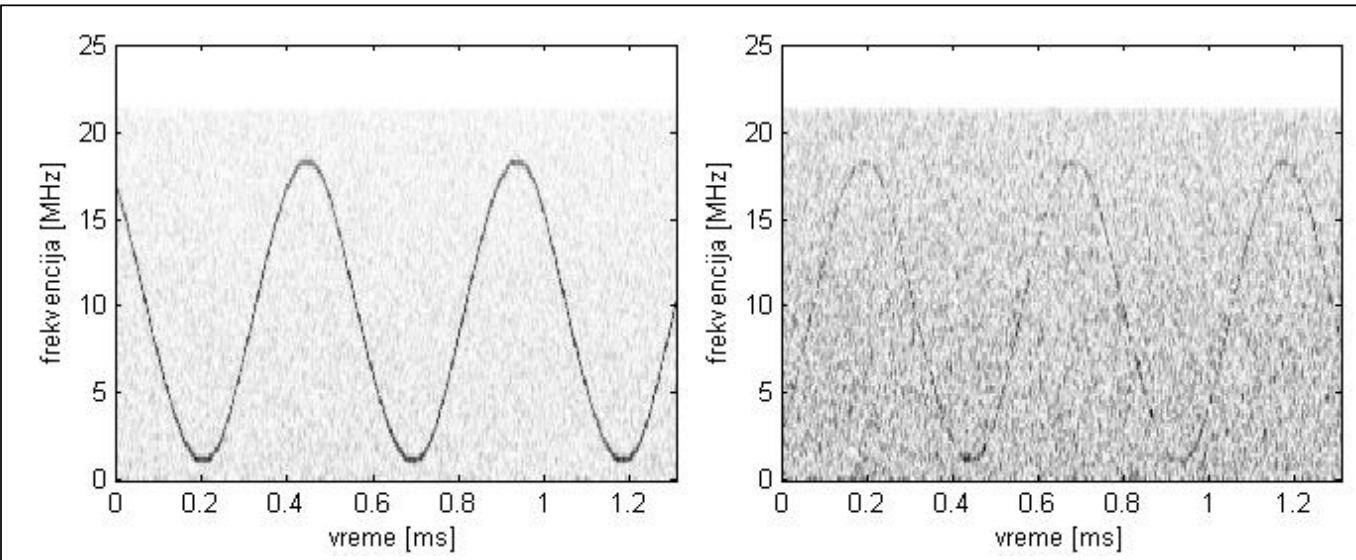

Sl. 9 - Spektrogram sinusnog FMCW signala: $S N R=0,8 d B$ (levo) $i$ SNR $=-11,4 d B$ (desno)
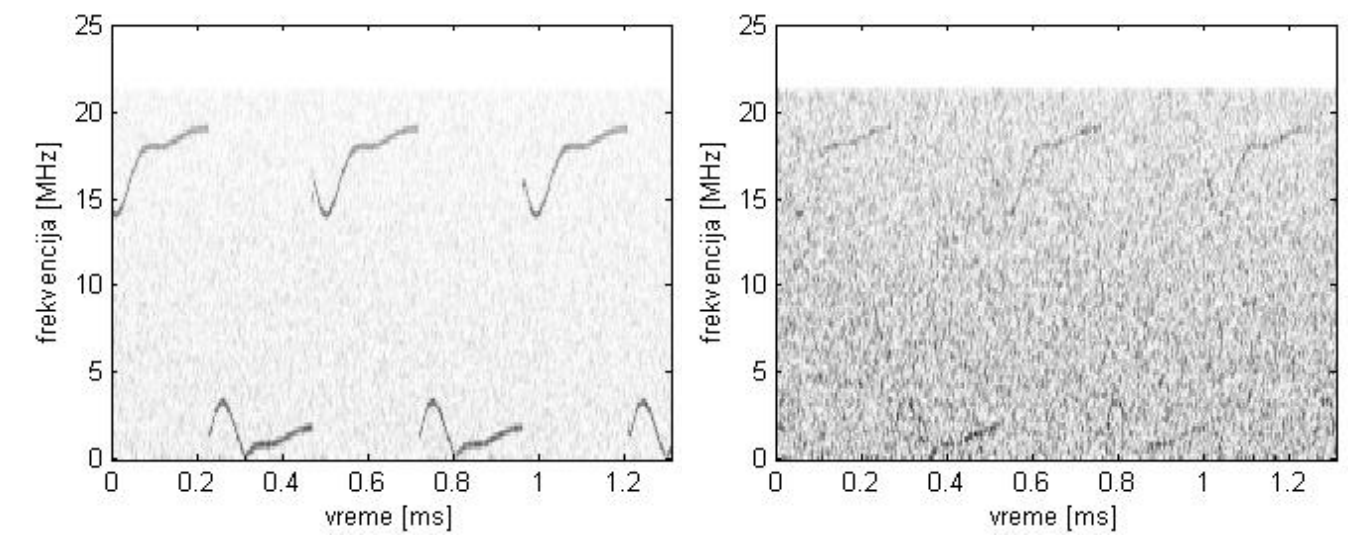

Sl. 10 - Spektrogram polinomijalnog FMCW signala: $S N R=-0,4 d B$ (levo) $i S N R=-13,2 d B$

Primljeni signal $r(t)$ deli se na nepreklapajuće ,prozore“ trajanja $T_{p}$. Tačna vrednost $T_{p}$ nije važna, ali ne sme biti manja od jednog perioda ulaznog signala, što je u radu i usvojeno. U idealnom slučaju prozor bi trebalo da sadrži samo jedan period signala $\mathrm{T}$, ali će algoritam ispravno raditi u širokom opsegu vrednosti $T_{p}$. Unutar svakog prozora procenjuje se autokorelacija:

$$
\hat{R}_{r r}^{(k)}(\tau)=\frac{1}{T_{p}} \int_{0}^{T_{p}} r(t) r^{*}(t-\tau) d t
$$

gde k označava redni broj prozora. Pomoću M prozora može se proceniti drugi moment procenjenih autokorelacija, koji predstavlja signal na izlazu iz detektora:

$\eta(\tau)=\frac{1}{M} \sum_{k=1}^{M}\left|\hat{R}_{r r}^{(k)}\right|^{2}$

Ako na ulazu postoji samo šum, $r(t)$ $=\mathrm{n}(\mathrm{t})$, onda se srednja vrednost $\mathrm{i}$ standardna devijacija amplitude signala na izlazu $\eta(\tau)$, mogu izračunati kao u [3]: 


$$
m_{\eta}^{(n)}=\frac{\sigma^{4}}{T_{p} W}, \quad \sigma_{\eta}^{(n)}=\frac{m_{\eta}^{(n)}}{\sqrt{M}}
$$

gde je W - širina propusnog opsega presretačkog prijemnika, a sufiks n označava da odgovarajuća veličina potiče od šuma. Utvrđeno je da treba odabrati prag detekcije:

$\eta_{p}=m_{\eta}^{(n)}+4 \sigma_{\eta}^{(n)}$

Kada na ulazu postoji signal pojavljuju se pikovi u $\eta(\tau)$, za one vrednosti $\tau$ pri kojima se impulsi u r(t) i r $(\mathrm{t}-\tau)$ poklapaju. Uz pretpostavku da signal i šum nisu korelisani, srednju vrednost ovih pikova čine dve komponente, od kojih jedna potiče od signala, a druga od šuma:

$$
m_{\eta}=m_{\eta}^{(s)}+m_{\eta}^{(n)}
$$

Komponenta srednje vrednosti koja potiče od signala izračunava se kao:

$$
m_{\eta}^{(s)}=\frac{T}{T_{p}} \bar{s}^{2}
$$

gde je $\overline{\mathrm{s}}-$ srednja snaga signala. Detekcija je moguća ako je srednja vrednost pikova iznad praga detekcije.

Ako se proces detekcije posmatra $\mathrm{u}$ diskretnom domenu, odnosno ako je ulazni signal diskretizovan $s$ periodom $T_{s}$, dužina prozora biće $\mathrm{L}=\mathrm{T}_{\mathrm{p}} / \mathrm{T}_{\mathrm{s}}$, pa se izraz (6) menja u:

$$
\hat{R}_{r r}^{(k)}(j)=\frac{1}{L} \sum_{i=1}^{L} r(i) r^{*}(i-j)
$$

Period odabiranja $\mathrm{T}_{\mathrm{s}}$ može se povezati sa širinom propusnog opsega presretačkog prijemnika W. Da bi odbirci šuma bili nekorelisani, mora biti $\mathrm{W} \geq 1 / \mathrm{T}_{\mathrm{s}}$. Biranjem najniže vrednosti za $T_{s}, W=1 / T_{s}$ i zamenom te vrednosti u (8) dobija se:

$m_{\eta}^{(n)}=\frac{\sigma^{4}}{L}, \sigma_{\eta}^{(n)}=\frac{m_{\eta}^{(n)}}{\sqrt{M}}$

Iz ovog izraza može se zaključiti da će varijansa šuma na izlazu iz detektora biti manja ukoliko su dužina prozora i broj prozora veći, odnosno što je interval posmatranja signala duži.

Imajući u vidu da je $T_{p}=L_{s}$, i da je $\mathrm{T}_{\mathrm{S}}=1 / \mathrm{BQ}$, gde je $\mathrm{Q}-$ faktor nadodabiranja, a B - širina frekvencijskog opsega koji zauzima posmatrani signal, to se zamenom vrednosti parametara $T_{s} i T_{p} u$ (11) dobija:

$m_{\eta}^{(s)}=\frac{Q \cdot T B}{L} \bar{s}^{4}$

Ovaj izraz pokazuje da će pikovi biti izraženiji pri većim TB proizvodima analiziranog signala.

Eksperimentalno dobijeni test-signali analizirani su pomoću opisanog algoritma. Cilj je bio detektovanje slabog radarskog signala, pri niskim odnosima signal/šum, od $-13,2$ do $-10,6 \mathrm{~dB}$. Na slikama 11-13 prikazane su amplitude signala na izlazu iz detektora (PACF), kada su na ulazu smeše signala (po jednog od tri prethodno navedena tipa) i šuma. Na raspolaganju je bio uzorak od $\mathrm{N}$ $=2^{21}$ odbiraka, što odgovara trajanju signala od $42 \mathrm{~ms}$. Jedini parametri algoritma koji se mogu birati su dužina prozora L i 
broj prozora $\mathrm{M}$, a oni su povezani relaci- lje rezultate sa porastom broja prozora jom $L \cdot M=N$. Na osnovu izraza (12) $M$, jer se time smanjuje varijansa šuma može se zaključiti da algoritam daje bo- na izlazu iz detektora. Dužina prozora ne
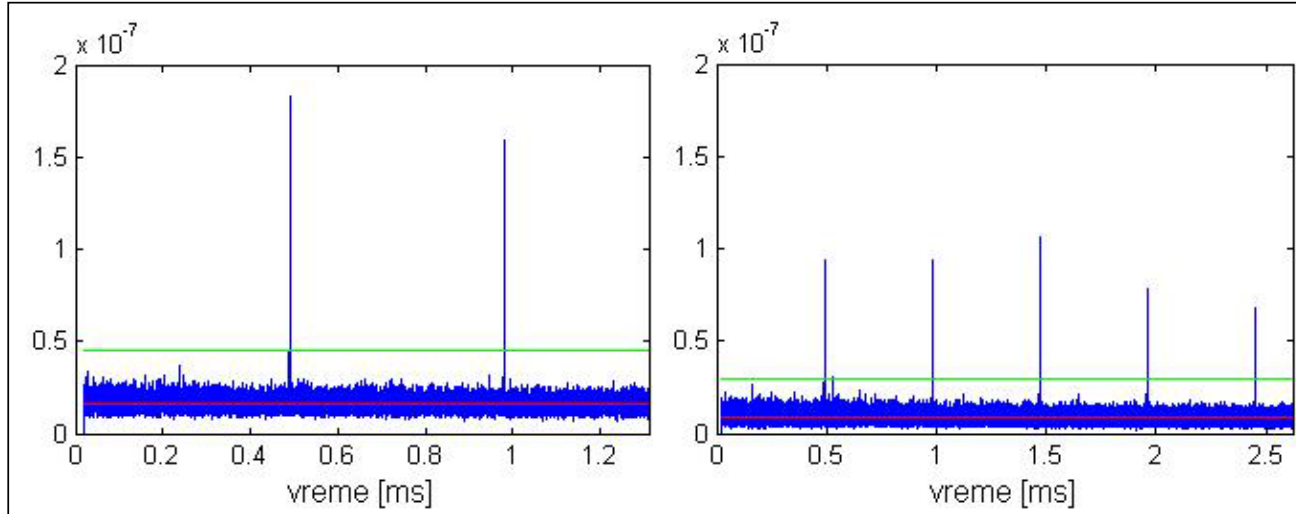

Sl. $11-P A C F$ linearnog FMCW signala: $L=2^{16}, M=32$ (levo) $i L=2^{17}, M=16$ (desno)
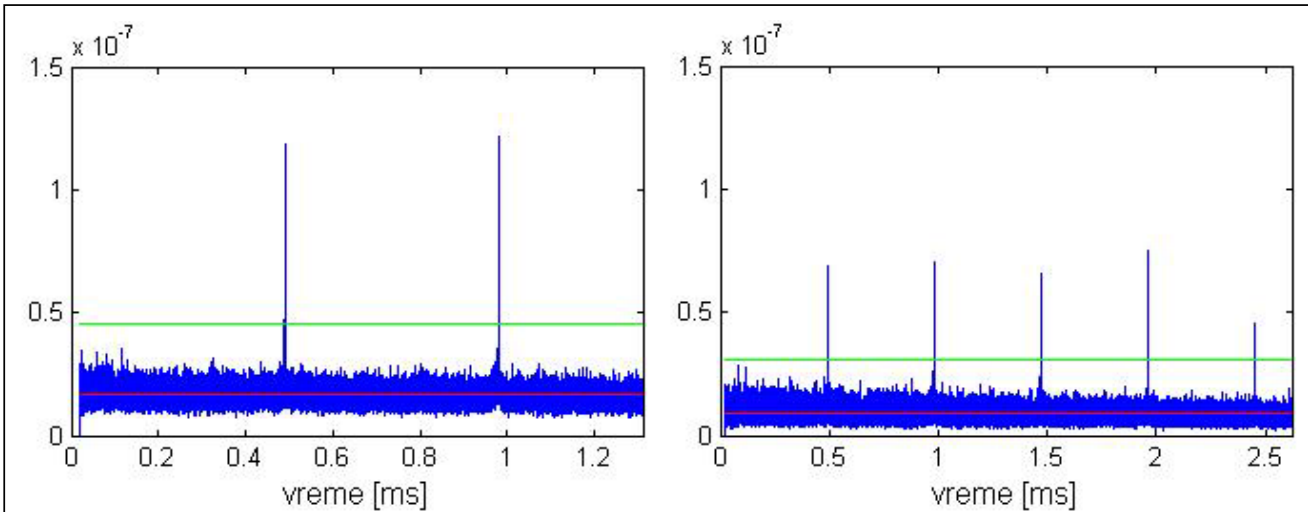

Sl. $12-P A C F$ sinusnog FMCW signala: $L=2^{16}, M=32$ (levo) $i L=2^{17}, M=16$ (desno)
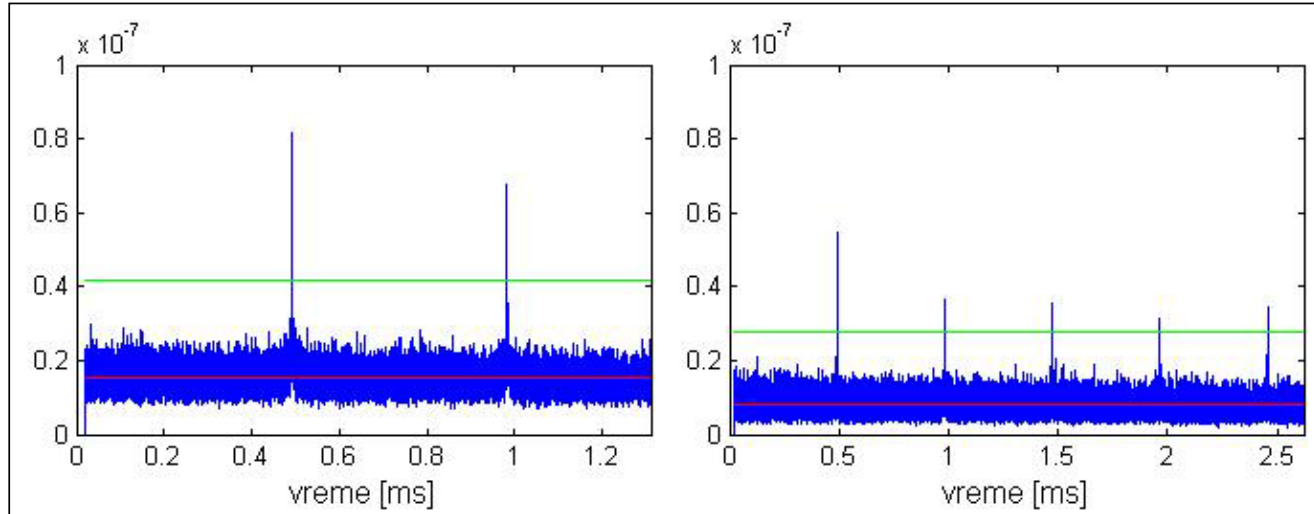

Sl. 13 - PACF polinomijalnog FMCW signala: $L=2^{16}, M=32$ (levo) $i L=2^{17}, M=16$ (desno) 
utiče znatno na rezultat izvršenja algoritma, jer se sa porastom L smanjuje i snaga šuma, ali i snaga signala (srazmerna vrednosti pika PACF) na izlazu iz detektora. Međutim, broj odbiraka u prozoru L ne bi trebalo da bude manji od broja odbiraka jednog perioda ulaznog signala. Imajući u vidu da se algoritam sprovodi pri nepoznatom periodu signala sa ulaza $i$ da je upravo procena ovog parametra jedan od rezultata ovakvog načina obrade, uvek se mora usvojiti veća vrednost L, da bi prethodni uslov bio ispunjen.

Da bi se sagledao uticaj izbora $\mathrm{M}$ i L, algoritam je sproveden za dva skupa vrednosti ovih parametara, ne ulazeći u razmatranje optimalnosti. U prvom slučaju algoritam se sprovodi uz veći broj kraćih prozora $\left(\mathrm{M}=32, \mathrm{~L}=2^{16}\right.$, odnosno 1,3 ms, levi delovi slika 11-13), a u drugom uz dvostruko manji broj dvostruko dužih prozora $\left(\mathrm{M}=16, \mathrm{~L}=2^{17}\right.$, odnosno 2,6 ms, desni delovi slika 11-13). Ove slike pokazuju da su pikovi mnogo iznad praga, dok odbirci šuma ne prelaze prag. Pri tome je nešto bolji rezultat kada je $(\mathrm{M}, \mathrm{L})=\left(32,2^{16}\right)$ nego kada je $(\mathrm{M}, \mathrm{L})=$ $\left(16,2^{17}\right)$. U drugom slučaju vrednost pikova je manja, ali je i varijansa šuma manja, pa je kod prva dva tipa signala ova razlika neznatna. Kod polinomijalnog FMCW signala razlika je primetna, što može biti posledica nižeg odnosa signal/šum, ali i niže vrednosti TB proizvoda, jer ovaj signal zauzima uži frekvencijski opseg (12 MHz) nego prva dva tipa signala (17 MHz). Iz dobijene PACF može se proceniti nepoznati period signala sa ulaza u detektor, ali ne i tip signala.

Kako je algoritam opisan u ovom odeljku zasnovan na proceni $\mathrm{PACF}$, to se on može primeniti na bilo koji talasni oblik čija PACF ima visok glavni, a niske bočne lobove. Primer takvih talasnih oblika su svi periodični radarski signali s visokim faktorom popune. To znači da je ovaj algoritam prilično robustan u odnosu na promenu tipa modulacije nepoznatog signala. S druge strane, promena perioda ponavljanja impulsa (od impulsa do impulsa) ili modulacionog perioda (od jednog do drugog) kod CW signala čini ovaj način obrade neefikasnim.

\section{Detekcija zasnovana na Radonovoj transformaciji}

Drugi metod analiziran u ovom radu zasnovan je na primeni vremensko-frekvencijskih transformacija zajedno sa tehnikama za prepoznavanje oblika [1, 2]. Na dobijene vremensko-frekvencijske slike (spektrograme) primenjivana je Radonova transformacija (RT), koja predstavlja projekciju matrice slike duž određenog ugla. U ovom slučaju to je preslikavanje iz [t, f] domena $\mathrm{u}[\mathrm{x}, \theta]$ domen. Ukoliko slika sadrži linearni segment $\mathrm{f}=$ $\mathrm{k} \cdot \mathrm{t}$, on će se projektovati $\mathrm{u}$ tačku $\left[\mathrm{x}_{0}, \theta_{0}\right]$, pri čemu $\mathrm{x}_{0}$ odgovara normalnom rastojanju segmenta (u pikselima) od centra slike, a $\theta_{0}$ je nagib segmenta $u$ odnosu na f osu, dakle $\operatorname{ctg} \theta=\mathrm{k}$. Vrednost RT u tački $\left[\mathrm{x}_{0}, \theta_{0}\right]$ biće veća ukoliko je linearni segment izraženiji u slici, bilo da je veće dužine ili da sadrži piksele većeg intenziteta. To znači da će, pri niskom odnosu signal/šum, pikseli od signala i pikseli od šuma u spektrogramu biti približno istog intenziteta, ali će prvi biti pravilnije raspoređeni, pa će doći do izražaja u RT. 


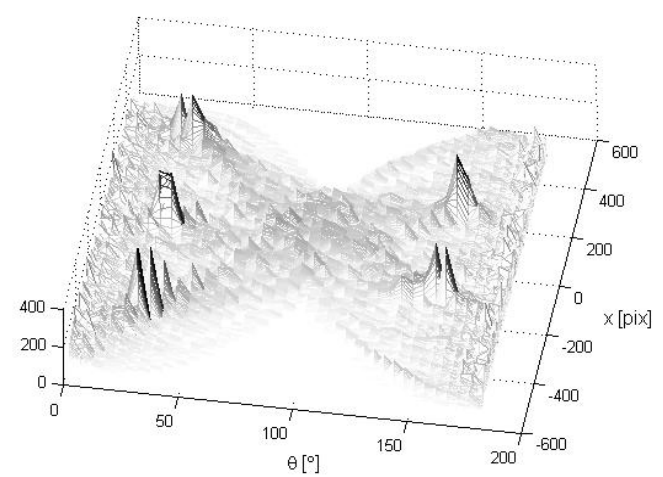

Sl. $14-R T\left[0^{\circ}, 180^{\circ}\right]$ spektrograma LFM signala

Na slici 14 prikazana je RT $\left[0^{\circ}\right.$, $180^{\circ}$ ] s korakom od $5^{\circ}$, primenjena na spektrogram sa slike 8 (desno). Jasno se izdvaja pet grupa pikova. U levom delu slike ističu se tri grupe pikova, sve tri pri istom uglu $\theta$ iz intervala $\left[20^{\circ}, 40^{\circ}\right]$, a različitom broju projekcije x (u pikselima). Ove tri grupe pikova potiču od tri približno prave linije, nastale usled rastuće promene frekvencije (slika 8), dok dve grupe pikova iz desnog dela slike potiču od tri približno prave linije, nastale usled opadajuće promene frekvencije (slika 8).

Zatim su u tako dobijenoj matrici izdvajani regioni s pikovima i računata je RT u okolini pika. Na slici 15 data je RT $\left[20^{\circ}, 40^{\circ}\right]$, s korakom od $1^{\circ}$, primenjena na spektrogram sa slike 8 . Jasno se izdvajaju tri pika, što znači da je detekcija ovakvog signala moguća i pri vrlo niskom SNR. Sto se procene parametara tiče, na osnovu jednog pika RT može se proceniti strmina promene trenutne frekvencije $(\theta)$ koja odgovara datom piku, zatim početna i krajnja frekvencija, koje se računaju na osnovu procenjenog ugla $\theta$ i broja projekcije za taj pik. Uzimajući svaki pik RT u obzir, nepoznati signal može se modelovati deo po deo.

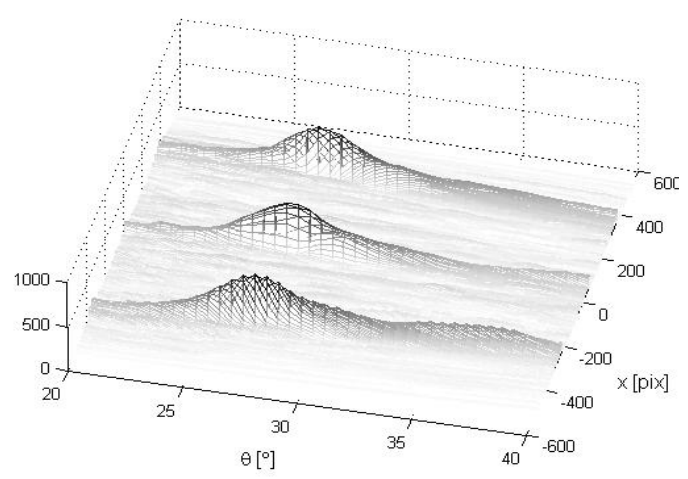

Sl. $15-R T\left[20^{\circ}, 40^{\circ}\right]$ spektrograma LFM signala

Međutim, ovi pikovi nisu oštri, već zaobljeni, što znači da tačnost procene $\theta$ nije bolja, u ovom slučaju od $1^{\circ}$, što je za mnoge primene nedovoljno, npr. za sintezu ometačkog signala. U tom slučaju moraju se koristiti kvadratne vremenskofrekvencijske distribucije (TFD, Time Frequency Distribution), koje imaju bolju rezoluciju. Međutim, njihovo izračunavanje je složenije, pored ostalog i zato što se ne može vršiti preklapanje kao kod spektrograma, pa bi dimenzije dobijene slike u ovom slučaju bile $2^{16} \times 512$, što znači da je RT takve slike apsurdno računati. Stoga se TFD primenjuju na mnogo kraći deo signala, reda 512 odbiraka, pa se dobijaju slike dimenzija $512 \times 512$. Kako bi se smanjio broj operacija, prvo se računa RT s većim korakom, npr. $\theta=$ $5^{\circ}$, od spektrograma signala dužeg trajanja, kako bi se odredili značajni regioni po vremenu i po uglu. Zatim se računaju TFD od kraćih uzoraka signala, a zatim RT, ali samo unutar značajnog opsega uglova, s manjim korakom, npr. $\theta=0,1^{\circ}$.

$\mathrm{Na}$ slici 16 prikazana je RT $\left[0^{\circ}\right.$, $180^{\circ}$ ], s korakom od $5^{\circ}$, primenjena na spektrogram sa slike 10 (levo). Pošto je reč o spektrogramu nelinearnog FM sig- 


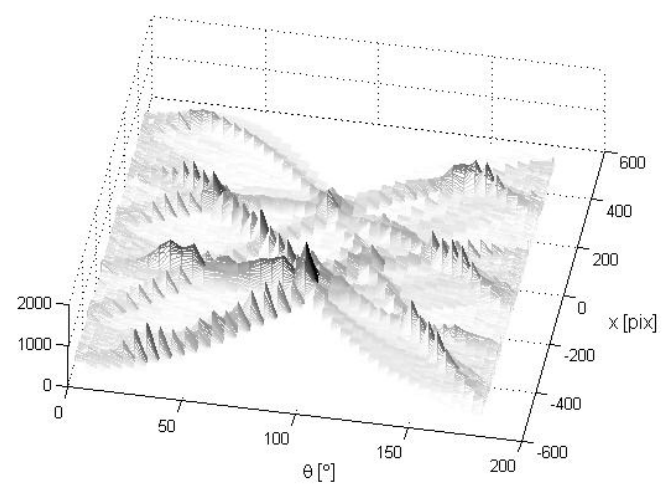

Sl. 16 - RT spektrograma PolyFM signala, $S N R=0 d B$

nala, koji sadrži krive linije, to se u RT javlja mnoštvo pikova, koji obrazuju nove krive linije, tako da procena parametara i modelovanje nepoznatog signala nisu jednostavni kao u prethodnom slučaju. Situacija se pogoršava pri ekstremno niskom odnosu signal/šum, što se vidi na slici 17 , gde je prikazana RT $\left[0^{\circ}, 180^{\circ}\right]$, s korakom od $5^{\circ}$, primenjena na spektrogram sa slike 10 (desno).

$\mathrm{Na}$ slici 18 prikazana je RT $\left[0^{\circ}\right.$, $180^{\circ}$ ], s korakom od $5^{\circ}$, primenjena na spektrogram sa slike 9 (desno). Rezultat je sličan kao na slici 14 , s tim što su pikovi sada izraženiji, iako je reč o nelinearnom, SinFM signalu. Međutim, ovaj

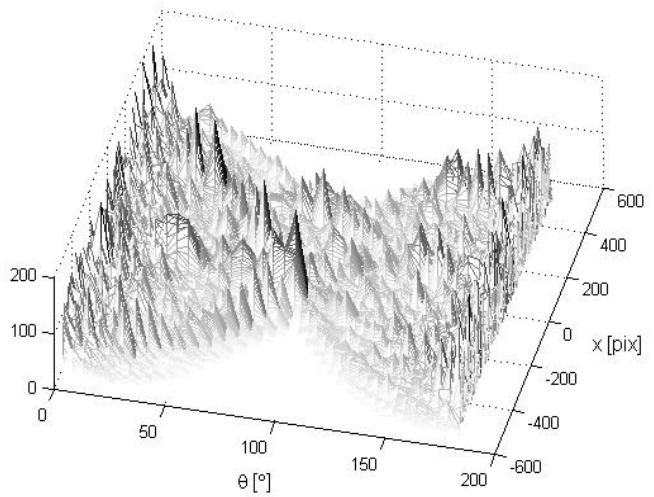

Sl. 17 - RT spektrograma PolyFM signala, $S N R=-13 d B$

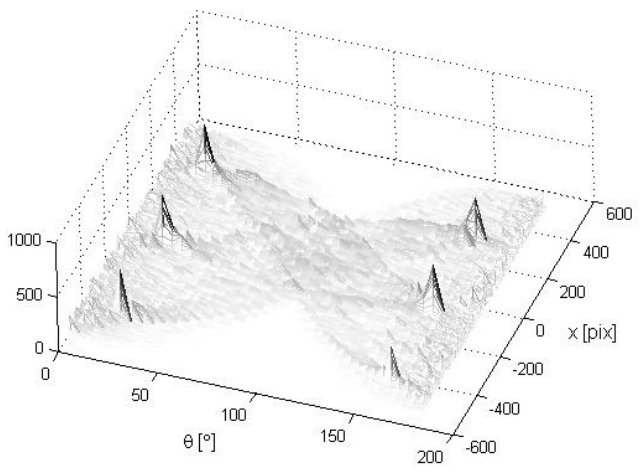

Sl. $18-R T\left[0^{\circ}, 180^{\circ}\right]$ spektrograma SynFM signala

signal $\mathrm{u}$ pojedinim delovima ispoljava veću linearnost od eksperimentalno dobijenog LFM signala, što se vidi poređenjem slika 8 i 9.

\section{Zaključak}

Primenom TFR i RT, FMCW signali mogu se uspešno detektovati i pri vrlo niskim odnosima signal/šum, reda $-12 \mathrm{~dB}$. Detekcija je bolja ukoliko TFR sadrže prave linije, odnosno ukoliko je promena frekvencije bliža linearnoj. Procena parametara drastično se pogoršava ukoliko promena frekvencije nije bliska linearnoj. Zato se u mnogim primenama signal posmatra $u$ dovoljno kratkim intervalima u kojima je promena frekvencije približno linearna [5]. To, s druge strane, zahteva češće računanje VFT, što usložava hardver kojim bi se navedena obrada realizovala.

Analiza signala na bazi spektrograma sprovodi se brže od analize na bazi TFD. Tačnost procene parametara u prvom slučaju dovoljna je za grubu klasifikaciju, po tipu modulacije, ali, uglavnom, nedovoljna za precizniju klasifikaciju unutar istog tipa modulacije, a samim tim ni za sintezu kvalitetnih ometačkih signala. Stoga se moraju ko- 
ristiti TFD. Njihovo izračunavanje je složenije, pa je vrlo bitno da se ima gruba početna procena parametara, kako bi se smanjio broj računskih operacija.

Pomoću algoritma koji se zasniva na proceni PACF uspešno se obavlja detekcija FMCW radarskog signala i pri ekstremno niskim odnosima signal/šum. $\mathrm{Na}$ osnovu izvršene analize zaključeno je da primena TFR i RT (koherentni metod) omogućuje procenu šireg skupa parametara $\mathrm{u}$ odnosu na procenu PACF-a (kroskorelacioni metod). Međutim, pri proceni PACF-a LPI radarskih signala ostvaruje se veće procesno pojačanje pri detekciji u odnosu na primenu koherentnih metoda, utoliko veće što je TB proizvod analiziranog signala veći.

Buduća istraživanja biće usmerena na ostale LPI talasne oblike. Pažnja će biti usmerena na istraživanje mogućnosti primene navedenih algoritama u rešavanju problema sa identifikacijom radara, tj. u slučaju kada je ulazni signal smeša talasnih oblika nekoliko radara, naročito kada je jedan od tih talasnih oblika dominantan, pa maskira ostale.

Literatura:

[1] Pace, E. Phillip: Detecting and Classifying Low Probability of Intercept Radar, Artech House, Norwood, MA, USA, 2004.

[2] Simić, S.: Detekcija i procena parametara nepoznatih radarskih signala s proširenim spektrom, Vojnotehnički glasnik br. 1, Beograd 2007.

[3] Burel, G.: Detection of Spread Spectrum Transmissions using Fluctuations of Correlation Estimator, Proc. of IEEE ISPACS, Honolulu, Hawaii, USA, November 5-8, 2000.

[4] Burel, G.; Quinquis, A.; Azou, A.: Interception and Furtivity of Digital Transmissions, IEEE Communications' 2002, Bucharest, Romania, December 5-7 2002.

[5] Cornu, C.; Ioana, C.; Quinquis, A.: Characterization of LPI Waveforms using Polynomial Phase Signal Modeling, International Conference on Radar Systems, RADAR 2004. 


\section{Predajnik FMCW signala}

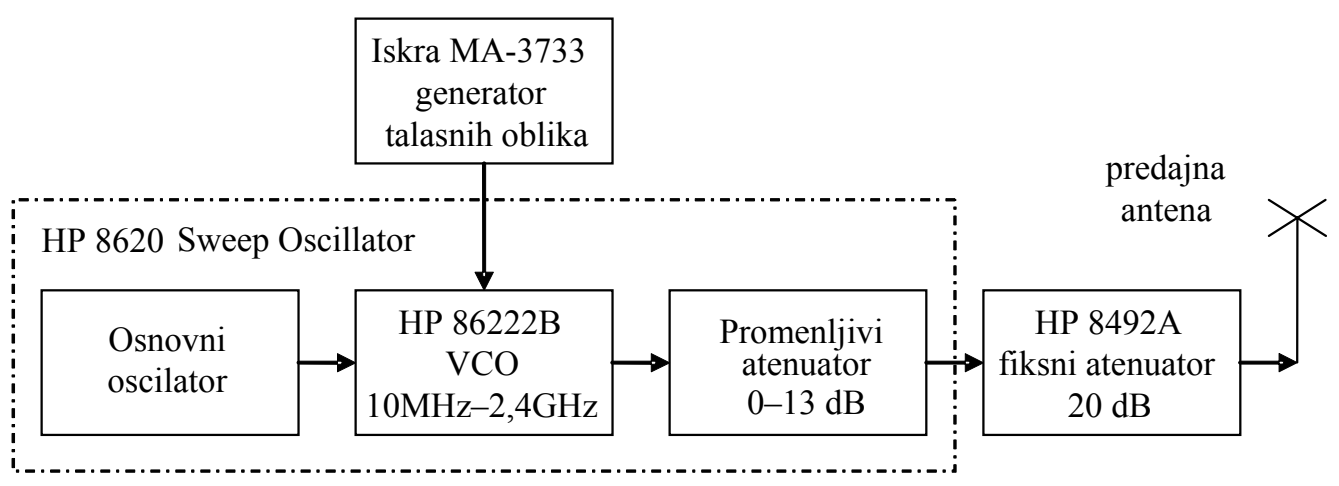

Sl. 1 - Blok-šema modela predajnika FMCW signala

\section{Softverski prijemnik LPI signala}

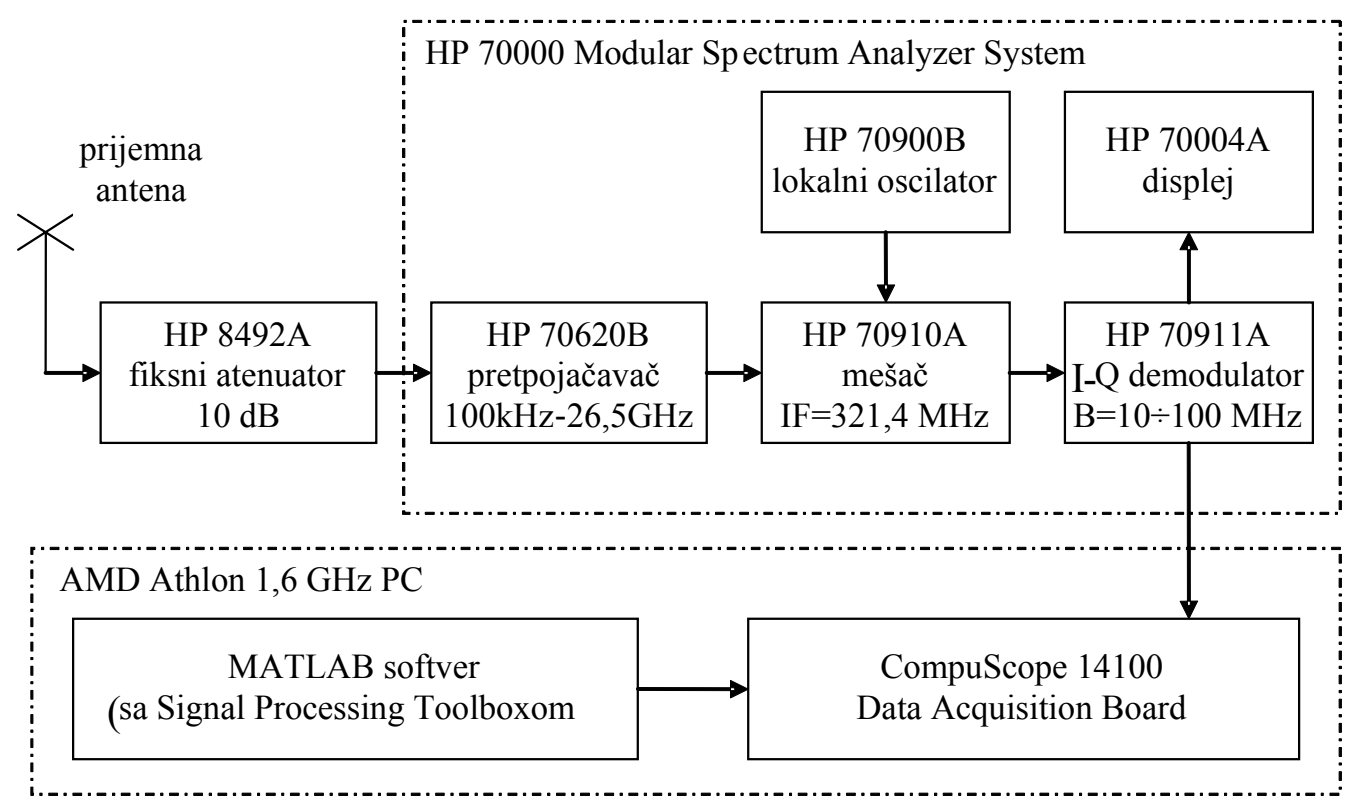

Sl. 2 - Blok-šema modela softverskog prijemnika LPI signala 


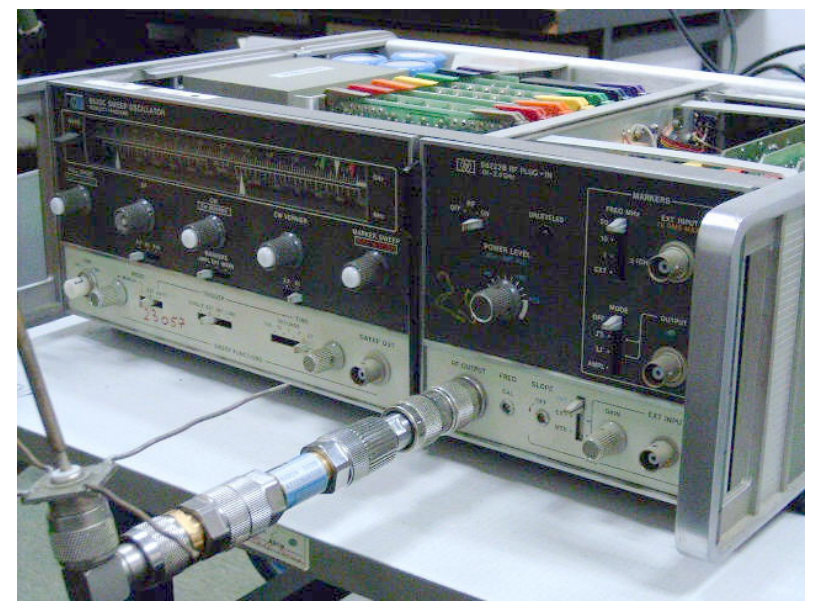

Sl. 3 - Predajnik linearnog FMCW signala

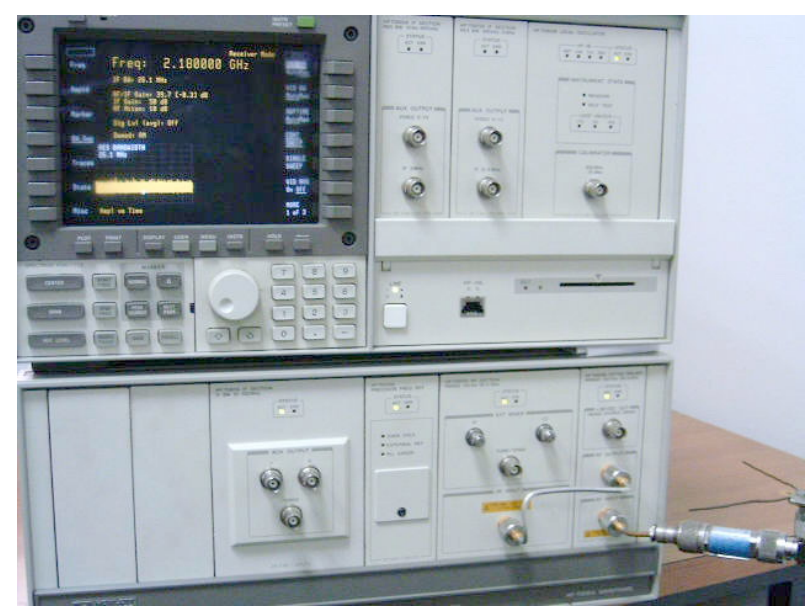

Sl. 4 - HP 70000 Modular Spectrum Analyzer 


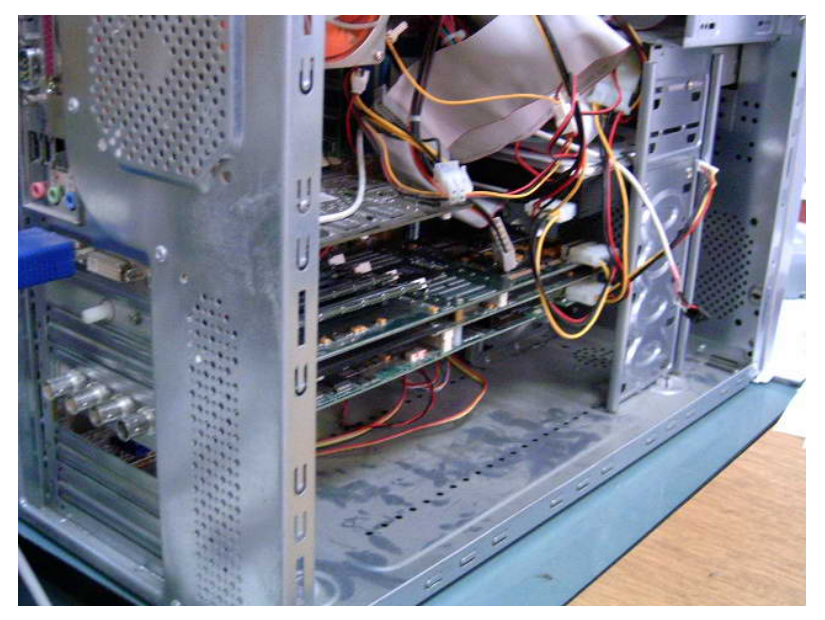

Sl. 5 - Digitalni deo prijemnika LPI signala

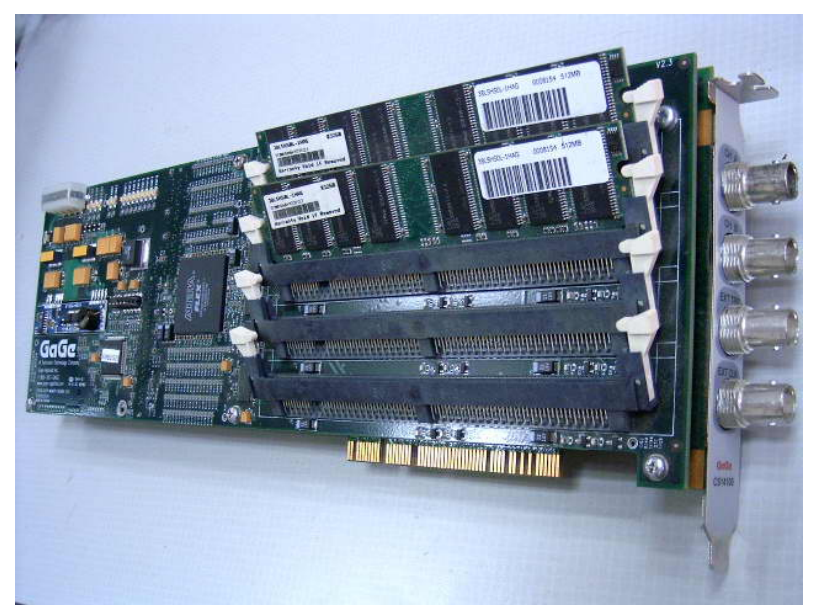

Sl. 6- Gage kartica, CompuScope 14100 

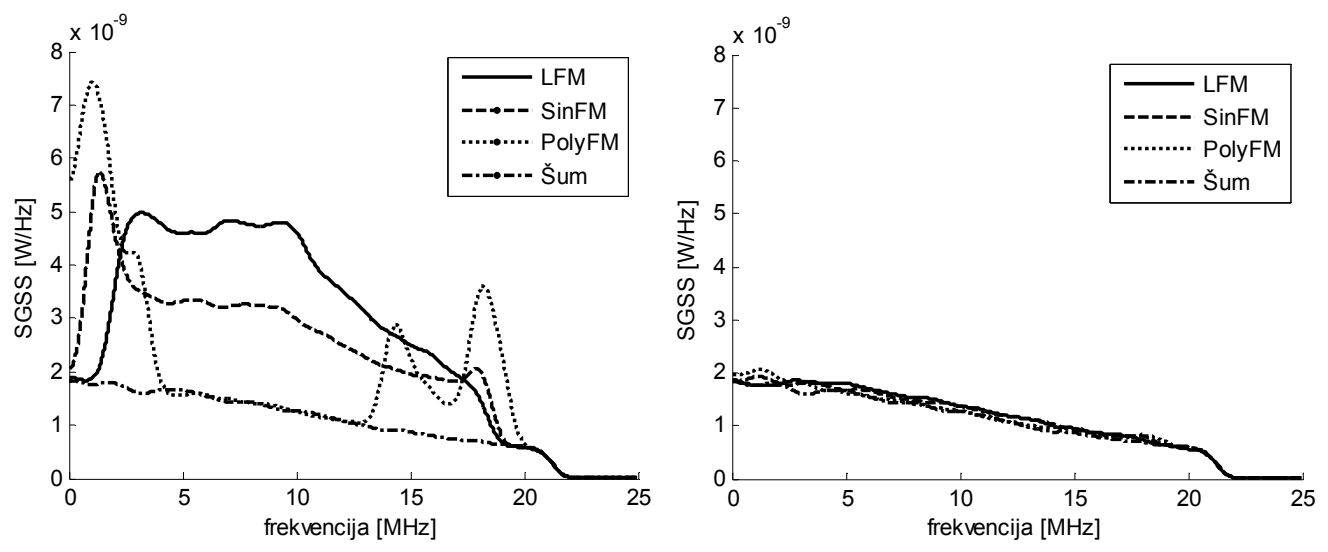

Sl. 7 - Spektralna gustina srednje snage primljenih signala: $S N R \approx 0 d B$ (levo) i $S N R \approx-10 d B$ (desno)
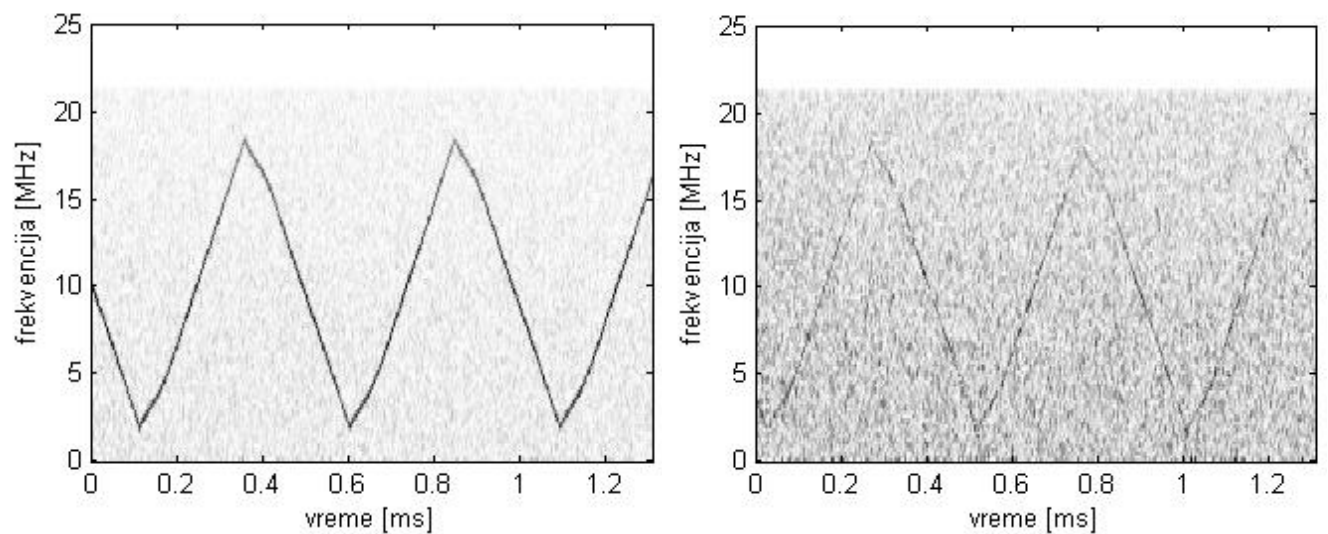

Sl. 8 - Spektrogram linearnog FMCW signala: $S N R=2,1 \mathrm{~dB}$ (levo) i $S N R=-10,6 \mathrm{~dB}$ (desno)
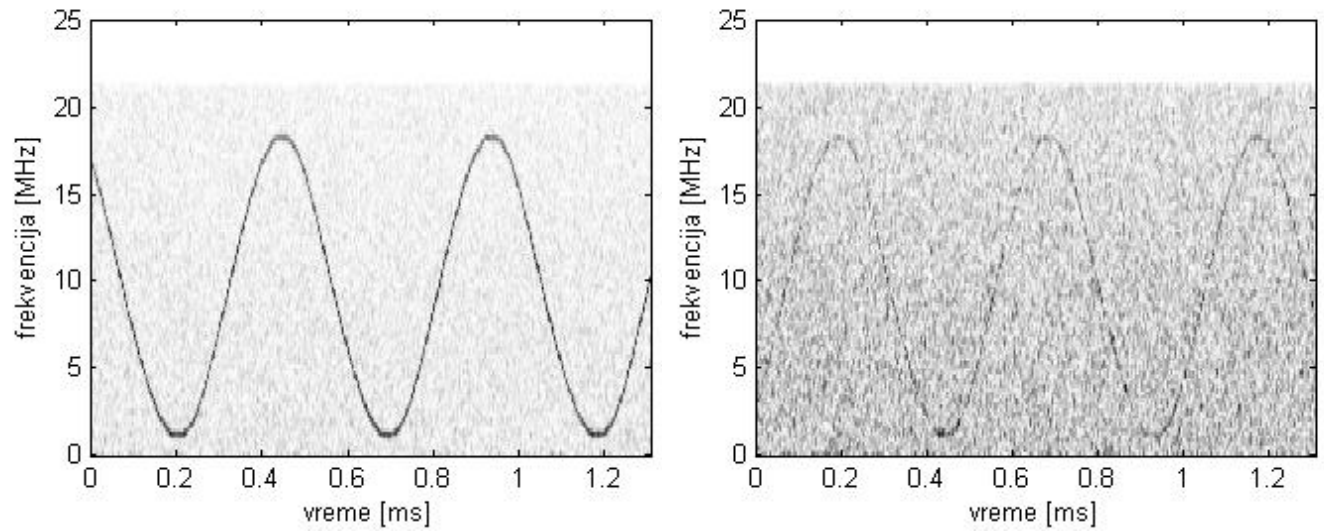

Sl. 9 - Spektrogram sinusnog FMCW signala: $S N R=0,8 d B$ (levo) $i S N R=-11,4 d B$ (desno) 

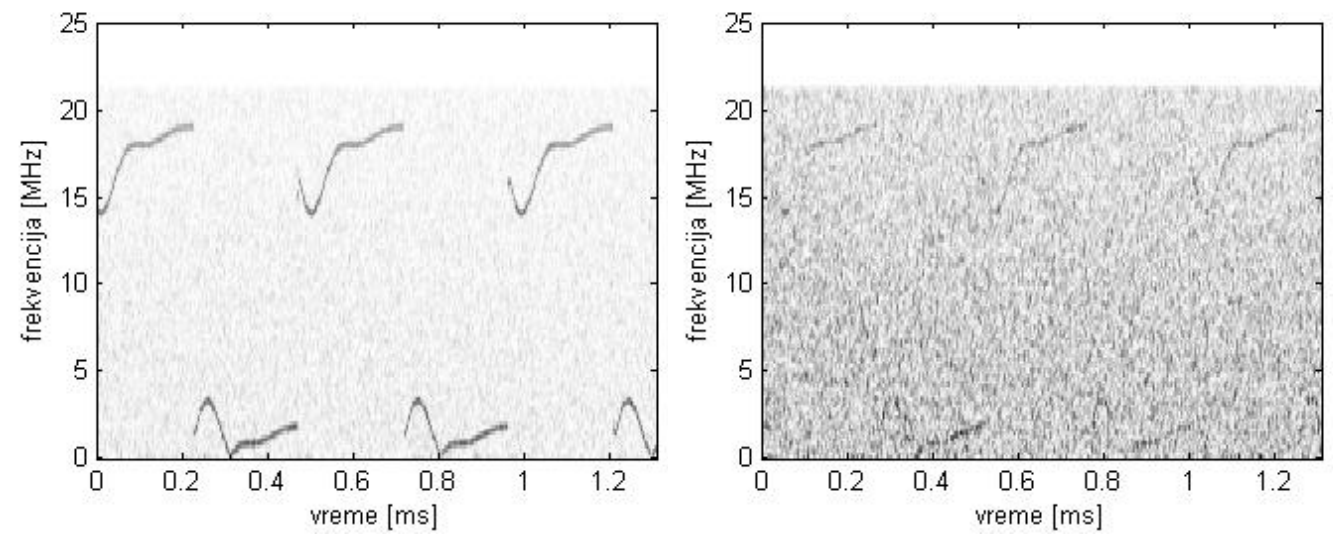

Sl. 10 - Spektrogram polinomijalnog FMCW signala: $S N R=-0,4 d B$ (levo) i $S N R=-13,2 d B$ (desno)
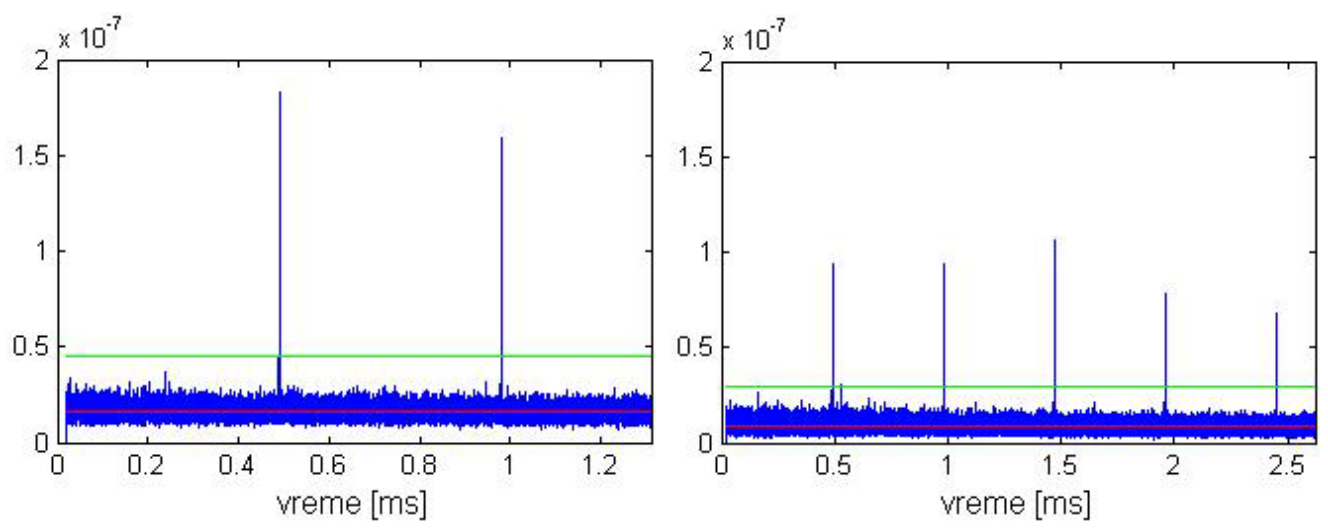

Sl. $11-P A C F$ linearnog FMCW signala: $L=2^{16}, M=32$ (levo) $i L=2^{17}, M=16($ desno $)$
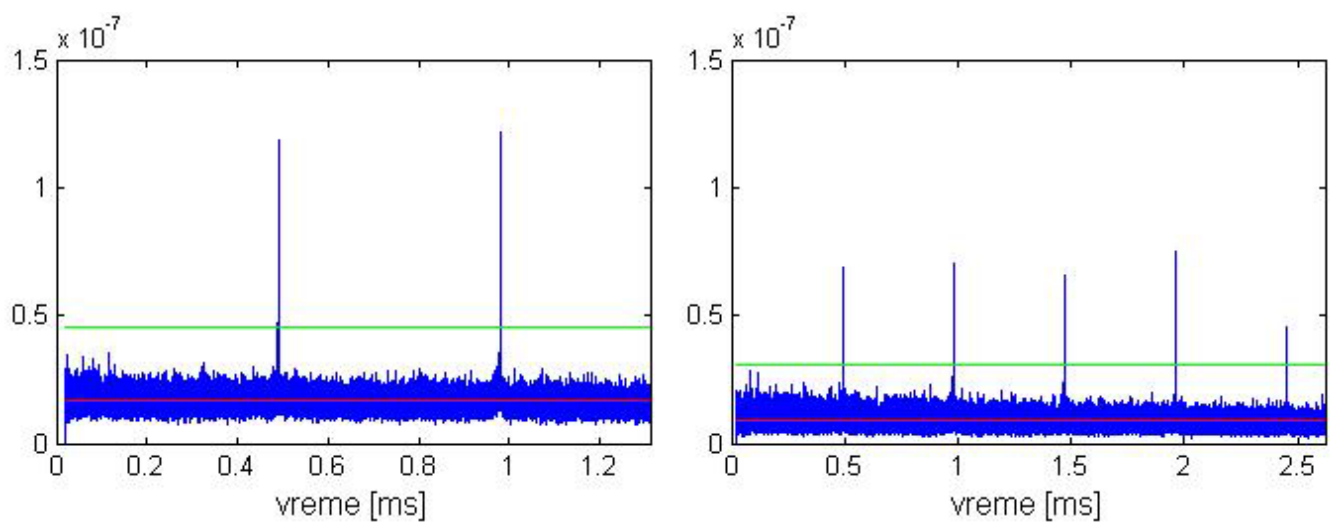

Sl. $12-P A C F$ sinusnog FMCW signala: $L=2^{16}, M=32$ (levo) $i L=2^{17}, M=16$ (desno) 

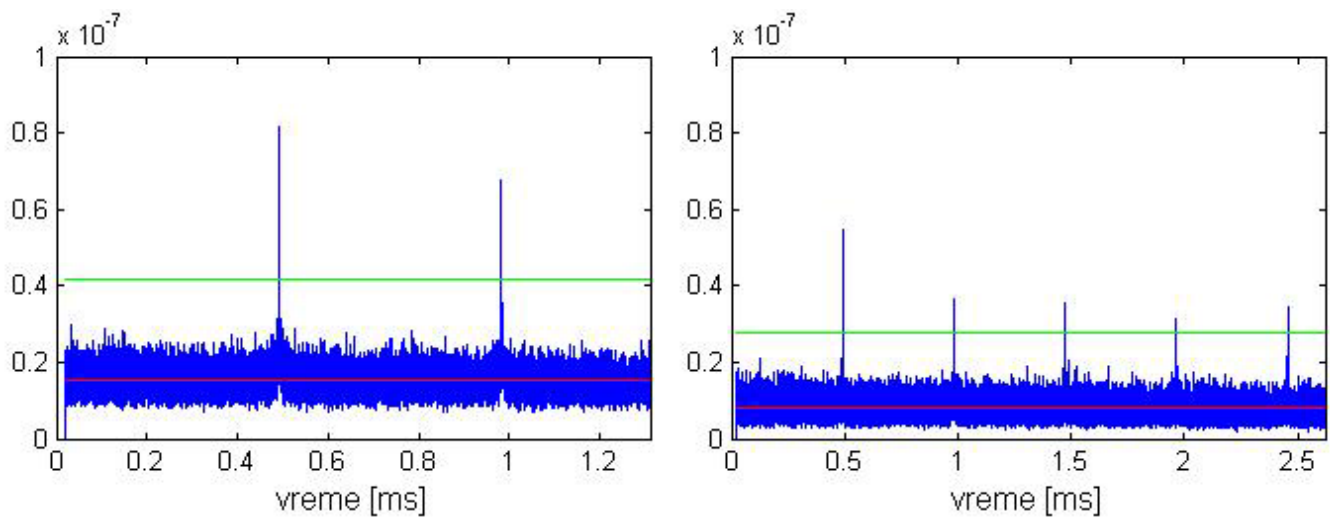

Sl. $13-P A C F$ polinomijalnog FMCW signala: $L=2^{16}, M=32$ (levo) $i L=2^{17}, M=16$ (desno)

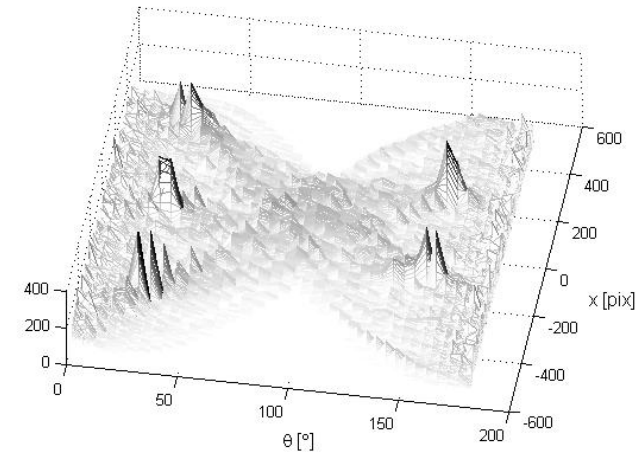

Sl. $14-R T\left[0^{\circ}, 180^{\circ}\right]$ spektrograma LFM signala

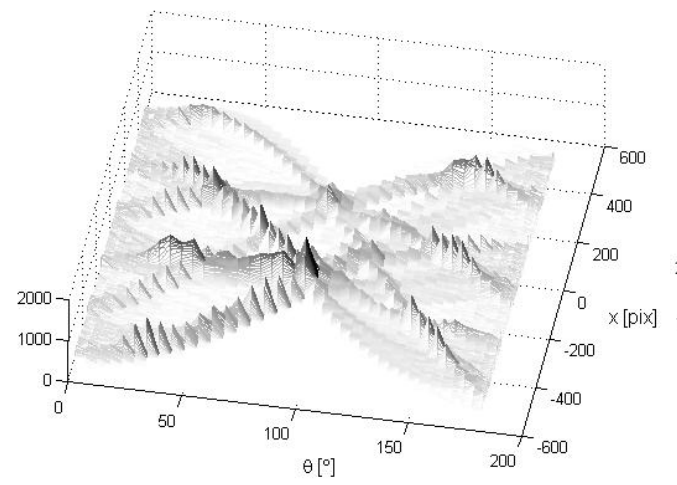

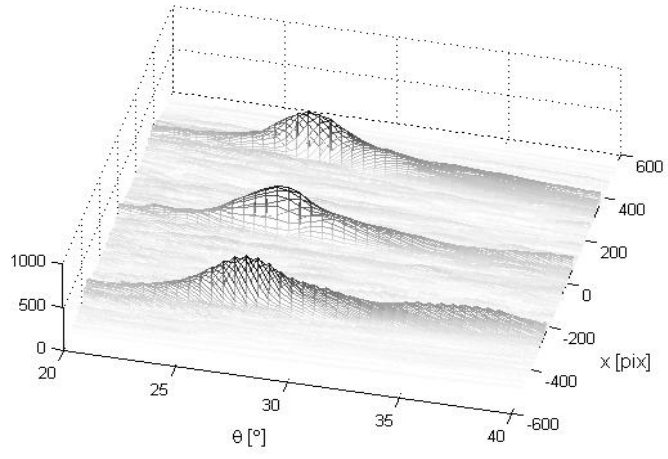

Sl. $15-R T\left[20^{\circ}, 40^{\circ}\right]$ spektrograma LFM signala

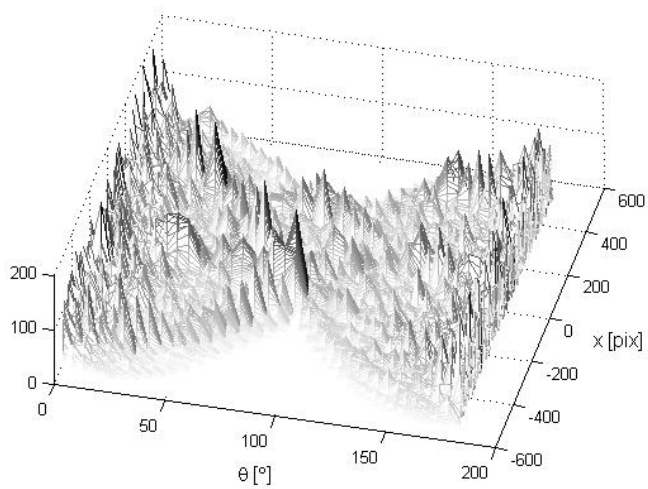

Sl. $17-R T$ spektrograma PolyFM signala, $S N R=-13 d B$ 


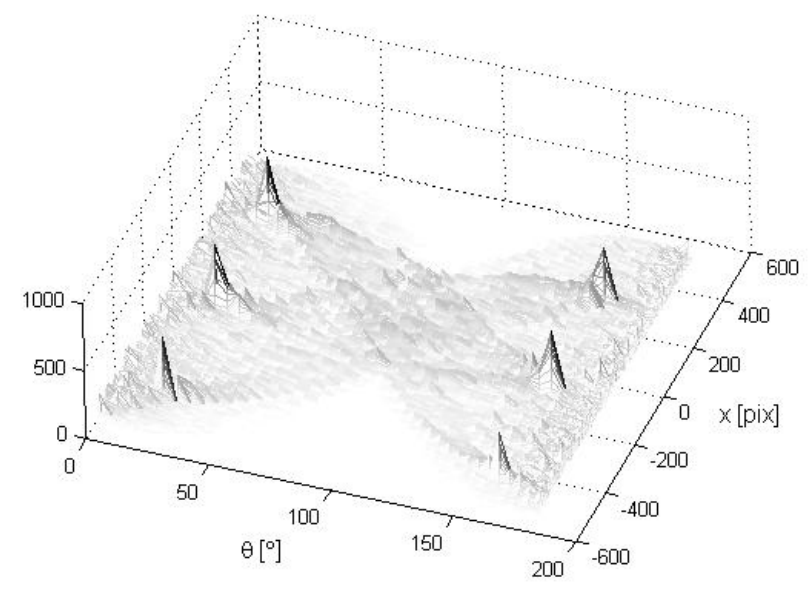

Sl. $18-R T\left[0^{\circ}, 180^{\circ}\right]$ spektrograma SynFM signala

Tabela 1

Srednjekvadratne vrednosti slučajnih procesa na ulazu u digitalni deo prijemnika i odgovarajući odnosi signal/šum

\begin{tabular}{|c|c|c|c|c|c|c|c|}
\hline Tip signala & \multicolumn{2}{|c|}{ Tip I (LFM) } & \multicolumn{2}{|c|}{ Tip II (SinFM) } & \multicolumn{2}{|c|}{ Tip III (PolyFM) } & \multirow{2}{*}{ Šum } \\
\hline $\mathrm{P}_{\mathrm{t}} / \mathrm{P}_{\mathrm{i}}[\mathrm{dB}]$ & 0 & -13 & 0 & -13 & 0 & -13 & \\
\hline $\begin{array}{c}\sigma^{2}[\mathrm{~mW}] \\
\text { po vremenu }\end{array}$ & 66,52 & 27,48 & 55,8 & 27,15 & 48,5 & 26,5 & 25,3 \\
\hline $\begin{array}{c}\sigma^{2}[\mathrm{~mW}] \\
\text { po frekvenciji }\end{array}$ & 67,6 & 27,32 & 56,0 & 27,2 & 48,14 & 26,6 & 25,37 \\
\hline $\begin{array}{c}\text { SNR [dB], } \\
\sigma^{2} \text { po vremenu }\end{array}$ & 2,1 & $-10,6$ & 0,8 & $-11,4$ & $-0,4$ & $-13,2$ & \\
\hline $\begin{array}{c}\text { SNR [dB], } \\
\sigma^{2} \text { po frekvenciji }\end{array}$ & 2,2 & $-11,1$ & 0,8 & $-11,4$ & $-0,5$ & $-13,1$ & \\
\hline
\end{tabular}

